\title{
11. The Forgotten Collection: Baskets reveal histories
}

\author{
Louise Hamby
}

The legacy of the 1948 American-Australian Scientific Expedition to Arnhem Land continues to be enhanced by analysis of the collections assembled by members of this unique enterprise. The assemblage of fibre objects - part of the bigger material culture collection-is, however, mainly forgotten. Due to the passion of the leader, Charles Mountford, much is known about the bark paintings but very little information has been published concerning fibre items. These pieces are made from fibres primarily from natural materials and are either worn on the body or used as containers. They can be for ceremonial or everyday use. Aboriginal women and men made these works at all the base camps - Gunbalanya (formerly Oenpelli), Groote Eylandt and Yirrkala - as well as on Milingimbi. This chapter brings together the dispersed group of fibre objects currently being held in the Australian Museum, the National Museum of Australia, the South Australian Museum and the National Museum of Natural History, a division of the Smithsonian Institution in Washington, DC, to reveal histories that connect people, place and time. The quantitative data concerning the fibre objects from all the base camps are used in the formation of general statements. It is, however, the collecting of Frederick McCarthy, from the Australian Museum, and Frank M. Setzler, from the Smithsonian Institution, that is integral to this study. Their collection of fibre objects from Milingimbi forms the core of this research. The examination of a smaller set of works from the overall ethnographic collection made by these men provides greater depth to the study by providing detailed analysis that can be applied to the objects from the other collecting sites. The fibre collection from Milingimbi can act as a metonym for the whole collection in the same way that Sally K. May has used the bark paintings. ${ }^{1}$

The material culture items collected from the Expedition are a valuable legacy for Aboriginal people and researchers. Many were made entirely from prepared or manipulated fibre. Fibre - such as hand-spun string made from plants, feathers, fur, human hair and wool-was also used as a binding component of other items collected such as spears. The fibre objects inform people today not only of what people were wearing but what they were doing and how

1 May, S. K. 2010, Collecting Cultures: Myth, politics, and collaboration in the 1948 Arnhem Land Expedition, Altamira, Lanham, Md, p. 14. See also May, S. K. 2000, The last frontier? Acquiring the American-Australian Scientific Expedition ethnographic collection 1948, BA (Hons) thesis, Department of Archaeology, Flinders University, Adelaide, p. xix. 
they were making things in 1948. As Martin Thomas has written, '[o]ne would never guess from the bulk of the filmic evidence that the people depicted wore western clothes and lived in mission housing' ${ }^{2}$ In contrast with the image that the Expedition wished to portray, this was a transitional time when people wore some Western clothes as well as some traditional items such as armbands. Women carried metal tins and also had specifically constructed baskets for yam collecting, while men had special baskets for their day-to-day equipment and for ceremonial occasions. Although people now had metal hooks for fishing, they also were still using butterfly nets knotted from hand-spun string. Because other manufactured materials were available, some of these things made their way into some of the classic items being made at this time, particularly by women. For example, manufactured dyed wool was incorporated into string bags and armbands, while cloth found its way into baskets. The string figures collected by McCarthy are unique items, made from manufactured string that he brought with him on the Expedition (see McKenzie, this volume). Manufactured items are incorporated into collected items but there is no evidence that any members collected complete articles of European clothing or metal buckets, for example. The members were consciously collecting items they regarded as 'authentic' to past traditions, not necessarily what was in everyday use.

Men, women and children used fibre objects in many aspects of life. My research reveals that fibre objects form the highest percentage of items of a particular category in the ethnographic collections. The quantities demonstrate the importance of these objects in Aboriginal everyday life outside missions and their exchange value within missions. My analysis has brought forward differences in collecting methodologies and generally attitudes between members of the Expedition. Most importantly, this research is initiating a reconnection between these objects and community members, revealing stories about the Yolngu who were influential in the formation of these collections and what they mean to people today.

\section{Distribution of Objects}

\section{Museum Numbers}

Determining exactly how many ethnographic objects were collected for the American-Australian Scientific Expedition to Arnhem Land is a difficult task. A complete inventory was not made in 1948. The objects were distributed across many institutions. For various reasons they might not have been catalogued at

2 Thomas, M. 2007, 'Taking them back: archival media in Arnhem Land today', Cultural Studies Review, vol. 13, no. 2, p. 25. 
the time, which increased the possibilities of errors. Equally difficult to establish is what items, and how many, went to which institutions. For this study, the interest lies with the distribution and complexities of the fibre objects.

Sally May has provided a baseline number of 2144 ethnographic items collected on the Expedition. She arrived at this number from museum register data. ${ }^{3}$ The category 'other objects' in May's breakdown includes works such as spearthrowers and belts. Other items that would be included in this figure are fibre objects that have not been specifically identified elsewhere in her chart.

Based on my research to date, the total number of fibre objects from the Expedition is 655. I have used individual museum registers as a starting point for analysis. After visiting all of the museums, I have been able to locate only 90.5 per cent of the objects listed in the registers. These 593 objects have all been viewed and photographed. These figures are subject to change as new items are found and might differ from the original numbers listed in diaries and records of the Expedition members.

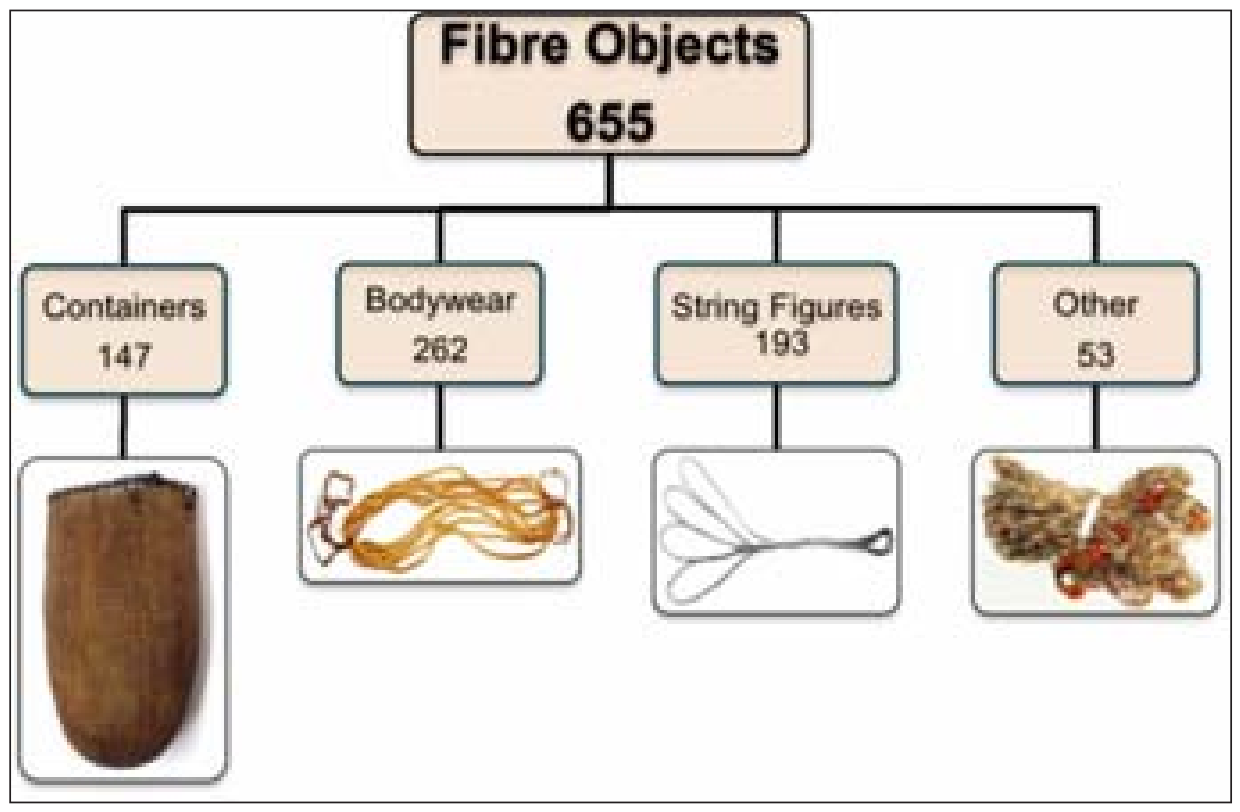

Figure 11.1 Number and type of fibre objects collected from all sites during the Arnhem Land Expedition

May's figures were obtained using the museum registers. In the past, museums would often give groups of items one registration number. With fibre objects, this most commonly occurred with armbands. A bundle of up to 30 could be

3 May, The last frontier?, p. 54; May, S. 2003, 'Colonial collections of portable art and intercultural encounters in Aboriginal Australia', Before Farming, vol. 1, no. 8, pp. 1-17, at p. 3. 
given the same registration number. This practice did not usually occur for larger items such as bark paintings, so the count for those objects is likely to be more accurate. Observations about types and numbers of objects collected based solely on registers can be skewed and are unlikely to give an accurate representation of what was actually collected at the time. In this case, the proportion of fibre objects is shown to be far greater than has hitherto been recognised. This is also the case with the numbers of paintings on paper, as shown in recent research by Sarah Bunn and Annaliese Treacy. ${ }^{4}$ In May's original figures, bark paintings represented 22.6 per cent of the ethnographic collection. By my reckoning, the fibre objects represent 30.5 per cent of May's total figure of ethnographic items.

\section{Geographic Spread}

The origins of the fibre items extended beyond the three base camps where they were collected, so the collection provides a broad picture of Arnhem Land fibre practice. Localities represented in the collection include Cape Stewart, Chasm Island, Delissaville (now Belyuen) and Elcho Island. One needs to take into consideration that some of the objects collected at a particular place were made by people who lived elsewhere. For example, Bessie Mountford describes a Milingimbi woman working at Yirrkala: 'Bali is making a basket, she says for me, in the coiled fashion. She is a Milingimbi woman, has been to school, and so versed in language and arts beyond the local women. ${ }^{\prime 5}$ It is not known if this particular basket is held in a museum collection; however, the Smithsonian does have one coiled basket from Milingimbi (E387541) that is discussed later in the chapter. If Bessie Mountford had collected this object, it would most likely be included in the Yirrkala grouping.

Milingimbi was an important collection site in 1948. It is an island less than $1 \mathrm{~km}$ from the mainland community of Ramingining. The island is at a low elevation, with mangrove and tidal mud flats dividing it into many sections. Pandanus and other small trees are common. Several clan groups live on the main island and nearby Mooronga Island in the Arafura Sea. Today's population is about 1500, but in 1948 there were around 400 people, 250 of whom regularly resided at the Methodist Mission. It is the collection site for the largest number of fibre items. For this study, Milingimbi has been selected for a variety of reasons, including my own knowledge base for the area, and the fact that more fibre objects were collected there than at the other sites. Other reasons include the collection rationale and methodology of Frederick McCarthy and Frank Setzler, who at this point were separated from the rest of the Expedition team.

4 Bunn, S. and Treacy, A. (Forthcoming), Australian Institute for Conservation of Cultural Material Bulletin, vol. 31 .

5 B. Mountford, 1948, Diary 3, Saturday 14 September, p. 62, PRG 487/1/2, p. 60, Mountford-Sheard Collection, State Library of South Australia (hereafter SLSA), Adelaide. 


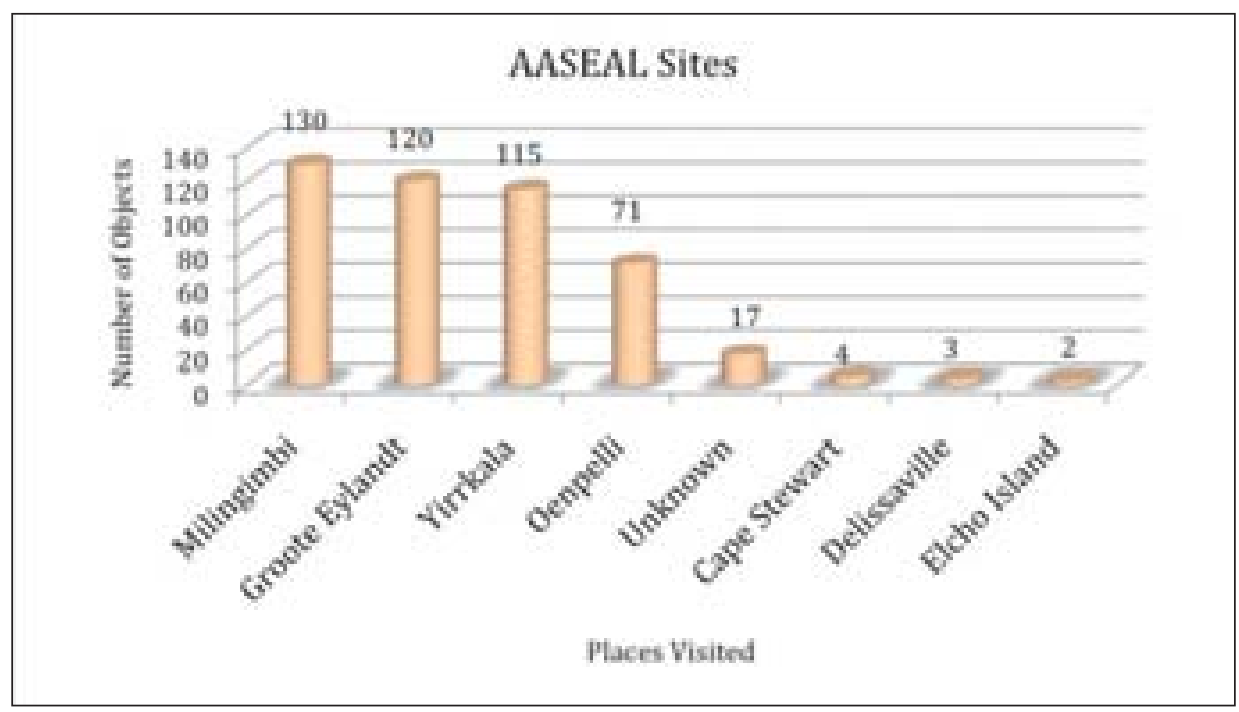

Figure 11.2 Distribution of fibre objects from sites visited by the Arnhem Land Expedition

\section{Milingimbi Camp}

\section{Background}

McCarthy and Setzler flew from Yirrkala to Milingimbi on 30 July 1948 in a RAAF DC3 Dakota plane. The Reverend Tom Hannah rode up on his horse and cart to collect them and their gear. ${ }^{6}$ Hannah was the superintendent at the Croker Island Mission but had been relieving for Reverend Alfred F. Ellemor for the previous seven months. It was a friendly start to their three-week stay at the Methodist Mission, which ended on 20 August 1948. The men were pleased with their accommodation at the laymen's house, a small two-roomed house with a screened verandah. They were more than delighted with the arrangement of eating at the main mission house with Tom Hannah, his wife and daughter, and having the missionaries take over the rationing and pay of the workers. ${ }^{7}$ This gave the men more time to concentrate on their archaeological excavations and ethnographic collecting.

6 F. McCarthy, 1948, Diary 4: Yirrkala Diary No. 1 F. D. McCarthy and Milingimbi, MS3513/14/4, Australian Institute of Aboriginal and Torres Strait Islander Studies (AIATSIS), Canberra.

7 F. M. Setzler, 1948, Groote Eylandt to Yirrkala to Milingimbi, vol. II, MS5230, National Library of Australia (hereafter NLA), Canberra. 
At Milingimbi, the men were free from the direct and daily influence of Mountford, but still constrained by systems he had put into place. McCarthy, by the time he went to Milingimbi, was distrustful of Mountford's intentions regarding the ownership and dispersal of collections:

$[\mathrm{H}] \mathrm{e}$ is not really concerned whether we get a collection or not so long as he gets a private collection of bark paintings which I believe he wants for the purpose of exhibitions \& lectures in the U.S. but I think he has cooked his goose and eaten it. It appears to be the general opinion in Darwin \& amongst the Missionaries that Mountford has made a mess of the leadership. ${ }^{8}$

Mountford had set up an account with Ellemor for collection purposes at Milingimbi. This covered the purchase of bark paintings and payment of wages. McCarthy's distrust was reinforced when a telegram arrived on 16 August directing McCarthy and Setzler to leave all the bark paintings and pipes with Ellemor. ${ }^{9}$ One outcome of Mountford's directive was that no bark paintings or pipes from Milingimbi reached the Smithsonian.

McCarthy and Setzler were happy to be at Milingimbi, despite the pressure of Mountford's demands. Their routine was quickly established, as it needed to fit with the operations of the mission and the Aboriginal men whom they employed. The mission cultivated a strong work ethic and Christian beliefs in the Aboriginal people. During the weekdays, work commenced about nine and finished at five, with a long lunch break. Friday was an exception. The Aboriginal men did not work on Friday afternoons because that was when the mission store was open. This was an opportunity for people to spend money on sweets, jam and tea. During working times, the two anthropologists were mostly engaged in archaeological work-mainly at the Macassan Well and Wallaby Mound. Apart from writing up results and marking specimens, the remainder of their time was mostly spent collecting ethnographic items. ${ }^{10}$

The lack of a stated collection policy for the ethnographic objects gave McCarthy and Setzler freedom to gather many types of objects. ${ }^{11}$ The attitudes, beliefs and work of a particular group of men were important to the approach and methodology taken by McCarthy and Setzler at Milingimbi. The group consisted of the American anthropologist William Lloyd Warner (1898-1970), the clergymen Hannah and Ellemor, and key Aboriginal men including Harry Makarrwala, David Milngawurruwuy, Gingi, Peter Muntjingu, Bill Balarra and Binyinyiwuy.

8 F. McCarthy, Diary 4, 1 August 1948, MS3513/14/4, AIATSIS.

9 F. M. Setzler, August 16 1948, Groote Eylandt to Yirrkala to Milingimbi, vol. II, MS5230, NLA.

10 Ibid.

11 May, The last frontier?, p. 63; May, 'Colonial collections of portable art and intercultural encounters in 


\section{The Legacy of William Lloyd Warner}

Warner's pioneering work at Milingimbi in the period 1927-29 was a guide for collection building and archaeology at all the Expedition base camps. Warner was the first person to perform excavations in Arnhem Land. McCarthy and Setzler drew upon his work. ${ }^{12}$ At Yirrkala, McCarthy used Warner's documentation of material culture from Milingimbi when directing Aboriginal people to make specimens. Setzler commented: 'McCarthy is feeling better and is checking types of material culture as reported by Warner. He will carry forward the directions for making those specimens. It all seems backwards, but that is our only method for obtaining ethnological specimens. ${ }^{\prime 3}$

This dependence on Warner's research was evident at Groote Eylandt as well. They had men doing bark paintings and making material culture items, based on examples collected by Warner. ${ }^{14}$ It is an oddity of the Expedition that Milingimbi's material culture from the 1920s was being reproduced by men in other communities whose styles were quite different. It demonstrates the influence and strength of the earlier work of Warner.

\section{Mission Pricing}

Milingimbi, since its establishment by the missionary James Watson, was known for its good reputation for dealing with Aboriginal people. In Watson's time, the mission became a place where fair trade was practised and men would travel for months with goods to trade. ${ }^{15}$ Subsequent missionaries, including T. T. Webb and Harold and Ella Shepherdson, carried on in this spirit. Selling material culture items to the mission encouraged people not only to work but to gain an income while supporting the mission's endeavours. The fibre items and other objects from Milingimbi were exchanged for a combination of trade goods and cash. The missionaries at Milingimbi had established prices for material culture items, as McCarthy documented in his diary:

They pay a basic price for each kind of article, sell it in Darwin, \& give the native the total less $10 \%$. Thus painted skulls are worth $£ 1$, bark paintings 10/- to $£ 1$ shovel-spears (iron) 4/- to 7/-, stone-headed spears 5-10/- baskets 5-10/- mats, $10-15 /$ \& so on. ${ }^{16}$

\footnotetext{
12 McCarthy, F. D. and Setzler, F. M. 1960, 'The archaeology of Arnhem Land', in C. P. Mountford (ed.), Records of the American-Australian Scientific Expedition to Arnhem Land. Volume 2: Anthropology and nutrition, Melbourne University Press, Carlton, Vic., pp. 215-95.

13 F. M. Setzler, 30 July 1948, Groote Eylandt to Yirrkala to Milingimbi, vol. II, p. 159, MS5230, NLA.

14 Ibid., p. 156.

15 Trudgeon, R. 2000, Why Warriors Lie Down and Die: Towards an understanding of why the Aboriginal people of Arnhem Land face the greatest crisis in health and education since European contact, Aboriginal Resource and Development Services Incorporated, Darwin, p. 29.

16 F. McCarthy, Diary 4, 1 August 1948, MS3513/14/4, AIATSIS.
} 
As the quotation makes clear, the mission's purchases included not only material culture items, but painted skulls - an issue to be discussed later. Mission pricing affected the trading of McCarthy and Setzler, who had at their disposal tobacco, a few combs, mirrors and razor blades, supplied by Mountford. Red combs were put to use, as can be seen in Howell Walker's photograph of Margaret McArthur and Aboriginal women at Oenpelli in the 1949 National Geographic article on the Expedition. ${ }^{17}$ Of the trade items provided by Mountford, the most coveted was tobacco. McCarthy pointed out that it would have been far better if Mountford had provided other items that people wanted, such as knives, tomahawks, shorts, shirts and belts. McCarthy regarded this as yet another failure in Mountford's planning. McCarthy noted in his diary that trading by Setzler sometimes got them into difficult situations due to standards and prices previously set by Ellemor. The mission paid a more equitable price for objects and also recognised their value.

In addition, Hannah points out (5 August) after Setzler had got some fine spears \& baskets that we should be paying more than we are for these specimens. We are now in an awkward situation-we want a good collection, we will have to pay a lot for it because of the mission standards, \& we will have to make up on the bark paintings. ${ }^{18}$

\section{Aboriginal Men}

In order to make their Milingimbi collection, McCarthy and Setzler needed the missionaries' assistance in finding men whom they could employ for archaeological excavations and to provide information about Aboriginal culture. Fortunately, the names of most of them are known. Setzler and McCarthy photographed them on 10 August 1948 and their names are noted on the sleeve housing the negative. ${ }^{19}$ On a recent trip to Milingimbi in 2009, I was given the updated spellings and other names for the men as they are now remembered in the community by Ruth Nalmakarra Garrawurra and Joe Neparrnga Gumbula. They are David Milngawurruwuy (Djambarrpuyungu), Gingi (Wobukarra), Peter Muntjingu (Gupapuyngu), Bill Balarra (Liyagawumirr) and Binyinyiwuy (Djambarrpuyngu). ${ }^{20}$ Both men mention, in addition to these workers, Harry Makarrwala and his son, Jackie, showing them sites and generally being helpful to them. These men's knowledge of English made work easier for McCarthy and Setzler. Makarrwala was the man who worked most closely with Warner during 1927-29. These named individuals would have brought material culture items to trade or would have told others to visit the researchers after work.

17 Mountford, C. P. 1949, 'Exploring Stone Age Arnhem Land', National Geographic, p. 766.

18 F. McCarthy, Diary 4, 1 August 1948, MS3513/14/4, AIATSIS.

19 F. M. Setzler, Photograph 36_milingimbi_22, Smithsonian Archives, Washington, DC.

20 Ibid; F. McCarthy, PhotographV08956.14.pcd4565.Img0051, Australian Museum Archives, Sydney. 


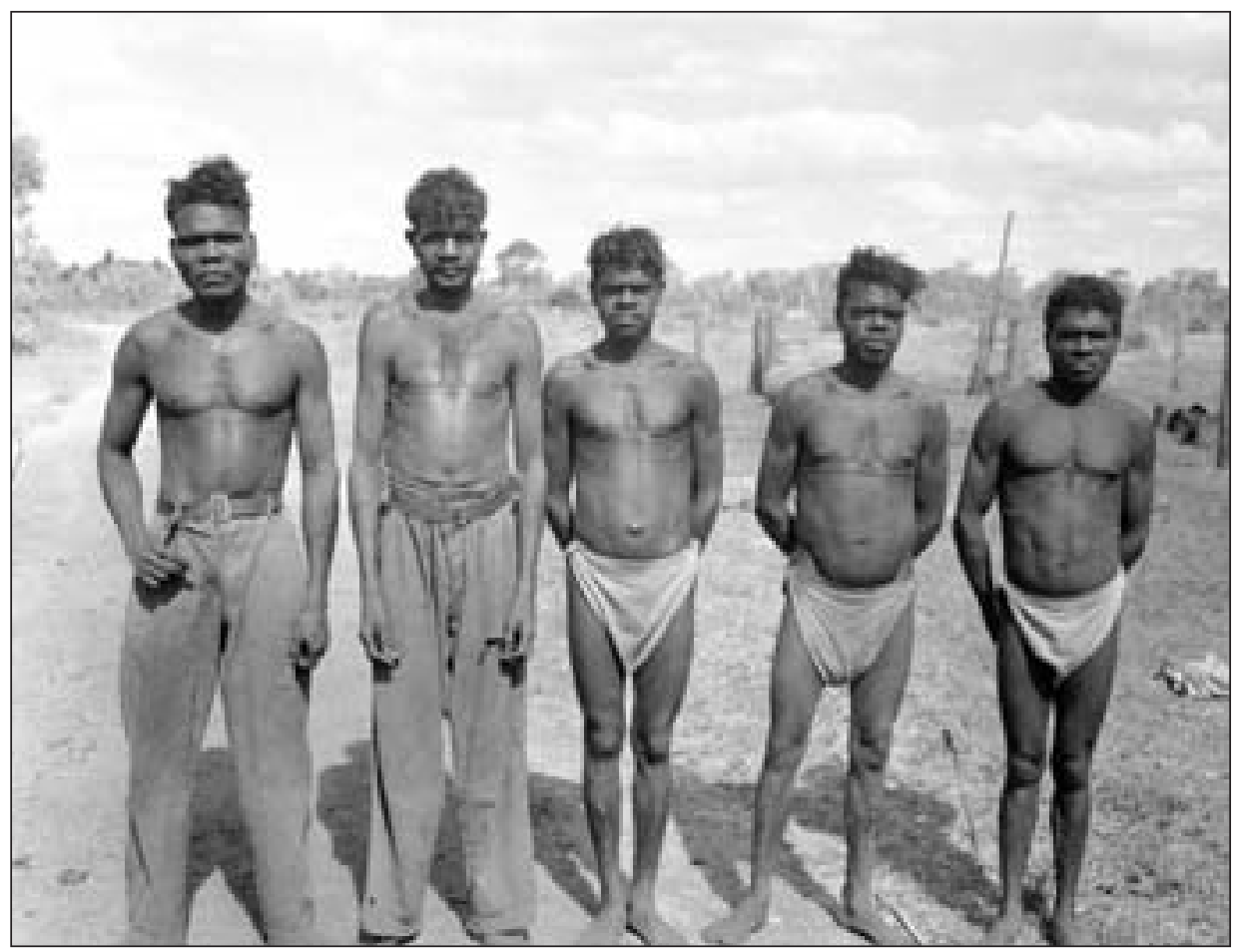

Figure 11.3 David Milngawurruwuy, Gingi, Peter Muntjingu, Bill Balarra and Binyinyiwuy on Milingimbi, 1948

Photograph by Frank Setzler. By permission of the National Anthropological Archives, Smithsonian Institution. Frank Setzler Photographs, Photo Lot 36, Box 8, Image 22.

\section{Ways of Collecting}

Setzler was very disapproving of Mountford's method of obtaining material culture. At the Oenpelli base camp, there were not many artists available to produce paintings for Mountford due to the fact they were working at the nearby buffalo-shooting camp. Mountford hired eight young men from Goulburn Island, who walked to Oenpelli once on the mainland, to make paintings. Setzler called them 'kids': 'At this date, October 20, it looks as though we shall not obtain any real ethnological specimens. Monty has had the Goulburn Island natives drawing. Some of the younger men have never attempted to paint, so he is trying to teach them, having them practice on paper.'21

At Milingimbi, Setzler's ideas about the appropriate ways of collecting ethnographic items were made clear:

21 F. M. Setzler, 2 October 1948, Oenpelli, vol. III, p. 242, NLA. 
Many specimens coming in are not those made to order - so to speakbut the actual specimens which they use in their everyday life. This turns out by far the best procedure - to purchase or trade for the things of their culture we desire, rather than have a group of natives fed by us make new things as we direct, rather than get the objects they actually use. This is a more orthodox way of collecting, I feel. ${ }^{22}$

Their collecting practice at Milingimbi seems to have conformed to this model. Whether or not this was based solely on conscious decision or whether it came about because they had little time to engage people after their archaeological work is not clear. McCarthy and Setzler felt that collecting everyday items was a better method than setting up artificial situations to obtain 'real ethnological specimens'. At Milingimbi, there was no need to direct individuals to make particular items as was done at other sites, where Warner's materials from Milingibi were used as templates. People brought items to them and they made their selections. As noted from the diary excerpt, they felt this was a better way of collecting than directing people to make specific items.

\section{Acquisitions}

According to Setzler's diary, trade with men first took place on 4 August 1948: 'Native boys brought 3 woomeras, 2 stone spear points hafted, 2 steel shovel spears, 2 stone spear points unhafted, a basket, and polished ax [sic] head. Bought all of them for a stick of native tobacco a piece. Big business. ${ }^{23}$

This passage shows us the variety of items coming in at an early date, as well as how Setzler was paying for the objects, mainly with tobacco. By 8 August, the collection was mounting. Concerning fibre objects, McCarthy stated they now had a dozen baskets and other ornaments. By this time, some disagreements were occurring between the two men in regard to the collecting process:

His [Setzler's] attitude is to get specimens as cheaply as possible, such as a basket for one stick of tobacco, but I believe that these poor natives should be given some reasonable value for the great amount of work involved in making a netted bag, twined basket, \& spear - we are paying more for bark paintings which take very little time, than for the objects which take a lot of time \& trouble. ${ }^{24}$

22 F. M. Setzler, 5 August 1948, Groote Eylandt to Yirrkala to Milingimbi, vol. II, p. 183, MS5230, NLA. 


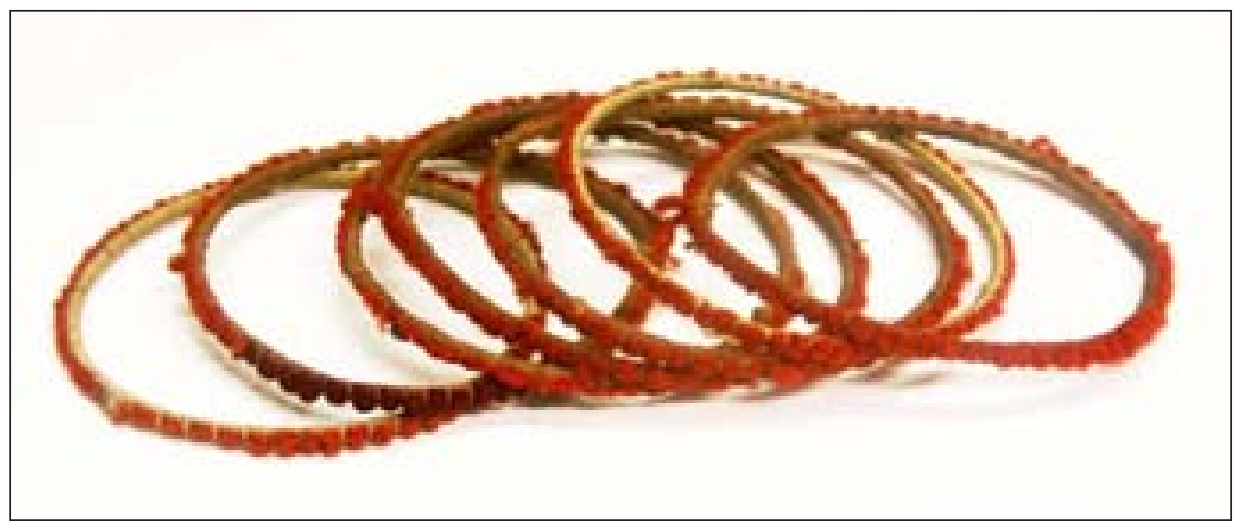

Figure 11.4 Group of armbands from Groote Eylandt

Photograph by Louise Hamby. By permission of the National Museum of Natural History, Smithsonian Institution. ID No. E387420B.

Frederick McCarthy had a strong interest in the fibre objects and an appreciation of the time required in their construction. The fact that makers of bark paintings (the men) were getting far more money than the other makers of equivalent items had become a matter of concern for him. The women were the main producers of fibre objects. This could have played a part in the prices they were paid for their work. May points to the fact that bark paintings would also sell for more money than the less 'aesthetically pleasing' items. ${ }^{25}$ Despite the anthropologists' disagreements and their lack of trade goods, collecting continued throughout the trip. Both men proved popular with people on the mainland, as well as with locals who came to trade with them. Mainland people and others came to Milingimbi to visit family, participate in ceremonies and trade. Some objects catalogued as being from Milingimbi have other place names written on them.

Most of the items in the Milingimbi collection were amassed by McCarthy and Setzler except for some works commissioned by Mountford and some that the anthropologists bought directly from the mission. These items included two tassel spear-throwers, two hafted stone axes, one necklet charm, four painted skulls, and three bone points. ${ }^{26}$ Other than the charm, these items are not the focus of this chapter-although they do deserve more research. The painted skulls and other skeletal material have recently been the subject of repatriation claims.

25 May, The last frontier?, p. 67; May, 'Colonial collections of portable art and intercultural encounters in Aboriginal Australia'.

26 T. Hannah, 1948, List of goods bought from the Mission by McCarthy and Setzler, August 1948, PRG 12188/17/9, Mortlock Library, Adelaide. 
McCarthy and Setzler were in agreement about the distribution of objects once they were collected. Setzler wrote in his diary while at Oenpelli how they shared bark paintings according to subject matter and took turns deciding who would have each one:

After lunch Monty, Fred, and I began sorting the bark paintings made by the Goulburn Island 'artists' and the Liverpool River guys. These are the worst lot of bark paintings collected. Most of them were made by kids who had never painted before and they were trying to imitate the old Oenpelli X-ray technique. Monty had picked out twelve of the best, which he had wrapped up, so we never even had a chance to see them. Then he insisted on having first choice of the large group from which we selected. Fred and I continued our old method of taking turns for first selection. What a contrast!!! ${ }^{27}$

After 10 days at Milingimbi, McCarthy was positive about the virtues of being there. He and Setzler were happy with their collecting and their work. He writes in his diary:

Milingimbi should certainly have been a base camp instead of Yirrkala. There are more natives, two bush camps at Gatji \& Cape Stewart within 30 miles, \& we could have got a wonderful collection, good dance sequences for films, \& sheltered...bases for the Nutrition Unit here. Preliminary inquiry by inspection would have revealed this to Mountford but he did not make a reconnaissance to properly investigate base camp sites - he picked them chiefly to study the bark painting art \& allow the others in the Expedition to fit in as best they could. ${ }^{28}$

\section{Discussion of Objects}

\section{Fibre Objects}

I have grouped all the fibre items collected by the Expedition into categories: bodywear, containers, string figures and other items. Bodywear includes all the items that people could wear, from headdresses to pubic covers. Containers from the Expedition include baskets, string bags and bark and palm containers. The last category of 'other items' comprises works few in number such as a head ring, a mat, raw materials, pendants and cordage. Many of the items are

27 F. M. Setzler, 30 October 1948, Oenpelli, vol. III, p. 262, NLA. 
made totally from a single plant fibre type such as pandanus for a basket, cane for an armband or unprocessed bark fibre for a head ring. Other items such as pendants contain multiple materials.

An examination of the representative types of objects collected during the Expedition provides a picture of items that were available for trade or purchase and that were in use in the communities at the time of the Expedition.

\section{Bodywear}

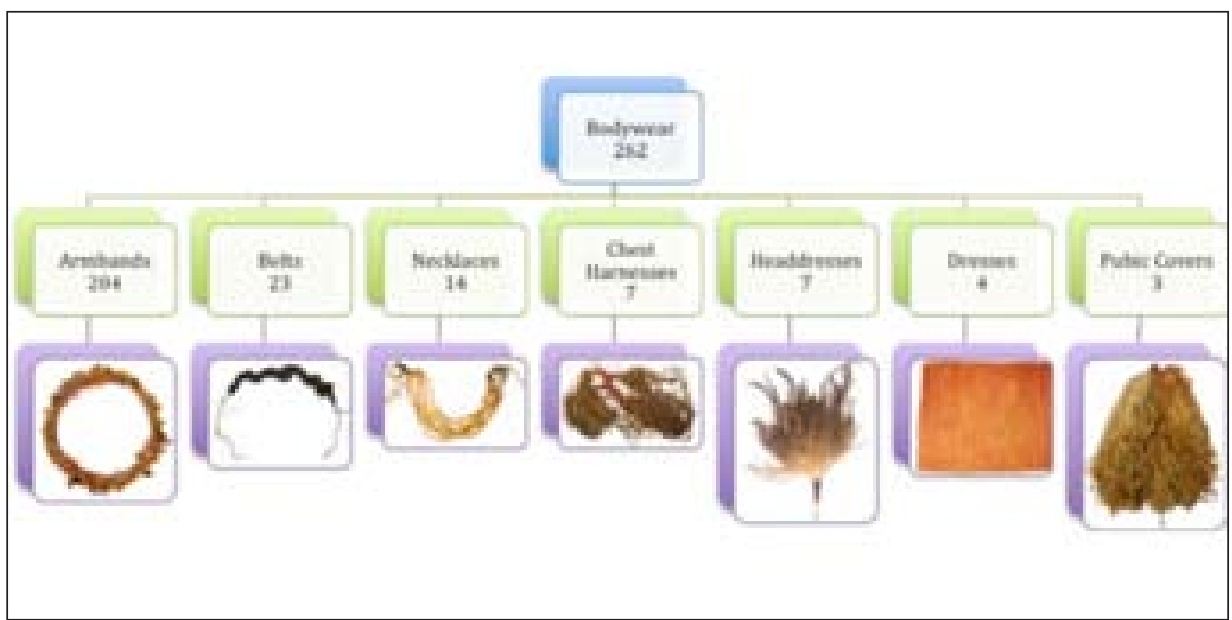

Figure 11.5 Items of bodywear collected at sites visited by the Arnhem Land Expedition

Most of the bodywear was made for everyday use, with armbands being the largest group. The most common type of armband is one that has an inner core of a strip of vine wrapped with plain, hand-spun string. The wrapped sort can be varied by the addition of small feathers, fur or wool wrapped or spun into the string. A variant has a wrapped band with attached feathered pendants. The other classic armband is interlaced from vine. Woven pandanus armbands, often painted with ochre, do not appear in major collections before the Expedition. Those from the Expedition come mainly from Groote Eylandt and Yirrkala.

Belts are the next largest category. They were made from hand-spun human hair or interlaced pandanus. Almost all of the necklaces are chokers made of grass stems threaded on hand-spun string. The remaining items - seven or less of which are represented in the collections - include pubic covers, bark dresses, headdresses and chest ornaments. 


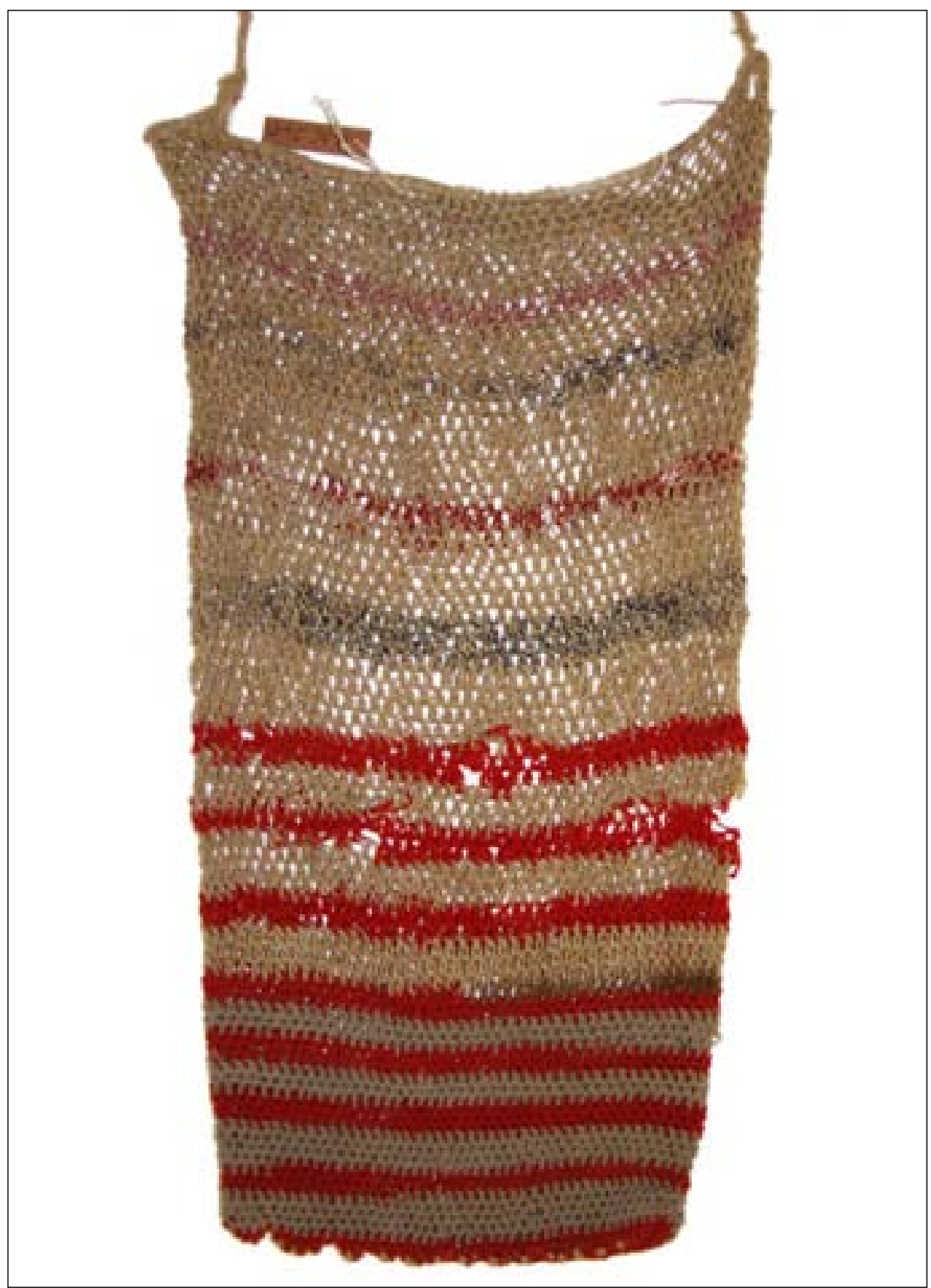

Figure 11.6 String bag from Yirrkala

Photograph by Louise Hamby. By permission of the National Museum of Australia. ID No. 1985.67.160. 


\section{Containers}

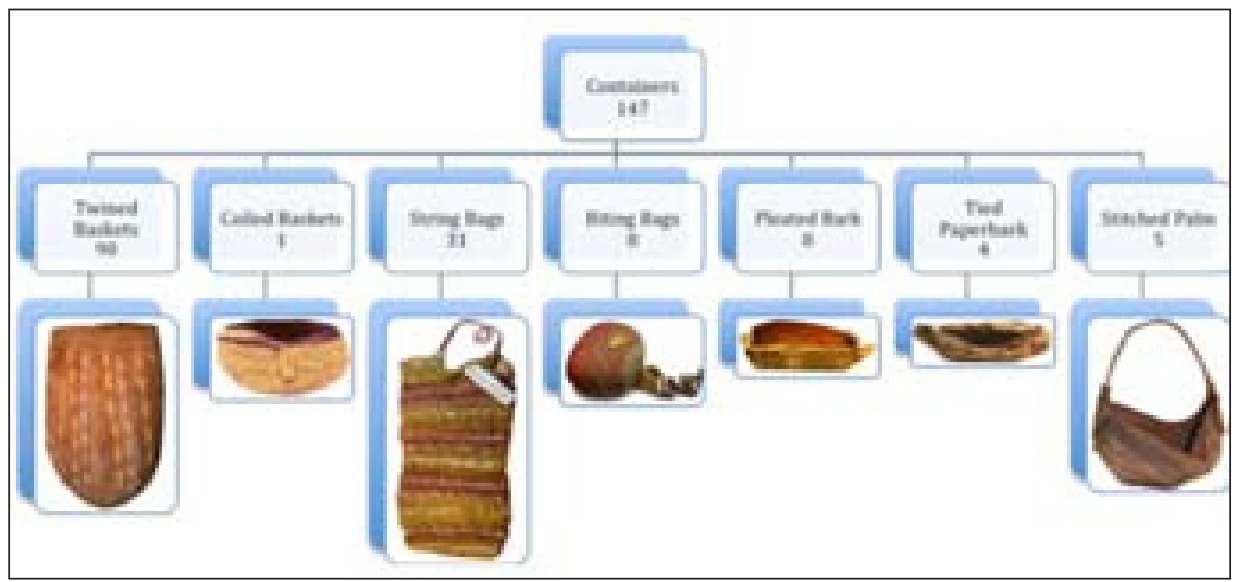

Figure 11.7 Containers collected at all sites visited by the Arnhem Land Expedition

Twined baskets made primarily from pandanus make up the largest group of containers. Included in the baskets is one exceptional coiled basket discussed later in the chapter. Some twined baskets are plain, while others are decorated with ochred feather pendants or rows of feathers woven into the body of the basket. About half of the looped and knotted string bags are biting bags, sometimes known as 'power bags' or 'spirit bags' and used in ceremony. They are stuffed with various materials and then tightly bound to make a rounded form. Bark containers include folded palm-leaf baskets, pleated stitched rigid bark containers and soft paperbark ones.

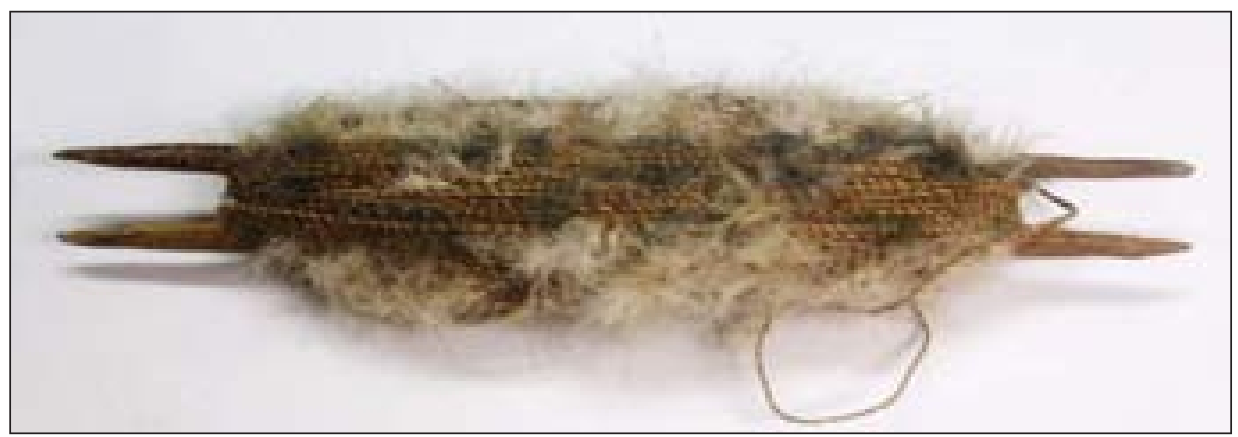

Figure 11.8 Shuttle from Yirrkala

Photograph by Louise Hamby. By permission of the National Museum of Natural History, Smithsonian Institution. ID No. E387479. 


\section{Other Fibre Objects}

Some of the items in this category are raw materials or objects made from them, such as feathered string. They were subsequently used in the fabrication of bodywear or containers. The largest group consists of cordage, ranging in scale from heavy rope to delicate feathered string. Pendants are among the 'other items', as they could be used for armbands or attachments to baskets. The pendants from the Expedition all contain red-orange lorikeet feathers. Other works include fans, shuttles, toys, raw materials, a head ring, a mat, a coconut shell and a sail.

\section{Milingimbi Quantities}

Examples of most items listed above appear in the Milingimbi collections. Towards the end of his stay on Milingimbi, McCarthy noted in his diary that they had 15 bark paintings and 213 other specimens. ${ }^{29}$ At the end of the trip, McCarthy and Setzler compiled an Ethnology Register that gives higher figures for items collected than those noted in the diary. The total number of ethnological items given in the register is 312. (The register did not include any of the bark paintings. $)^{30}$ Of the objects listed, 127 were fibre and the remaining 185 a mixture of weapons and other items. For the Milingimbi fibre objects, there is an anomaly in number: 53 baskets are listed, but I have found only 43 . This means that 19 per cent of the baskets are not to be found in the museums. What has happened to them?

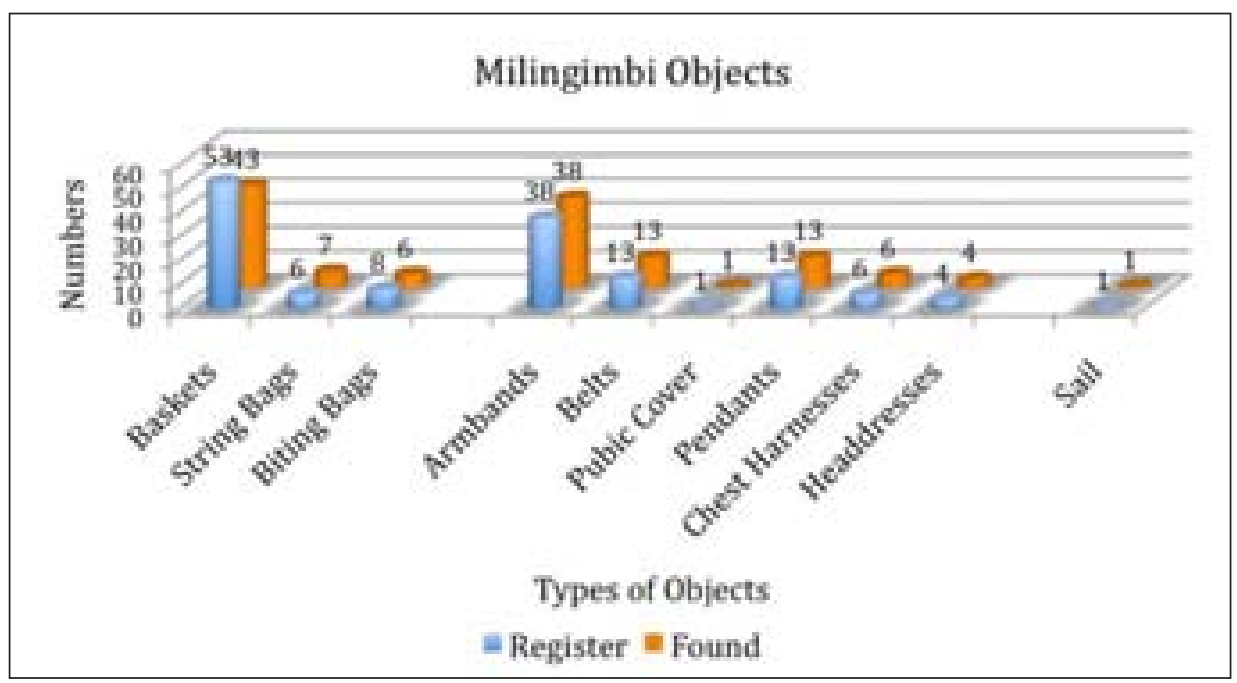

Figure 11.9 Comparison of fibre objects listed in McCarthy and Setzler's Ethnology Register with actual objects in the collections of the National Museum of Australia, the South Australian Museum, the Australian Museum and the National Museum of Natural History, Smithsonian Institution

29 Ibid., 14 August 1948, p. 57. 
Works collected on the Expedition are held in institutions that were not part of the original distribution scheme. For example, the Kluge-Rhue Collection at the University of Virginia has one of the paintings on paper that appeared in Volume 1 of the Records of the American-Australian Scientific Expedition to Arnhem Land. ${ }^{31}$ It was purchased by John Kluge in 1995 from Museum Art International. ${ }^{32}$ It is not known where or how Museum Art International obtained the painting. Sally May's Table 6.1 in her honours thesis lists all the items missing from their home institutions. None of these is from Milingimbi. ${ }^{33}$ She does provide information on two of the missing baskets from Milingimbi: one was stolen while on loan to the Commonwealth Department of Trade and one was exchanged. In September 1949, McCarthy started corresponding with W. W. Bowen, Director of Dartmouth College Museum, to arrange an exchange of North American baskets for Australian material. ${ }^{34}$ In January 1951, the basket numbered E52808 arrived at the Hood Museum of Art. ${ }^{35}$ This ochred basket has now been given a new registration number and is housed with other Australian objects that were exchanged. ${ }^{36}$

For the fibre objects there are a few possibilities to explain their absences. Some objects have been registered and have subsequently been lost in the years since the Expedition and are listed as 'missing' or 'location pending'. The collection managers and myself could have made mistakes in ascertaining whether certain objects are indeed from the Expedition. Some might have been incorrectly attributed or, as in the case of the painting, some might have been kept by Mountford or other Expedition members. May supports this idea, noting that 'unofficially, Charles Mountford was selling and giving away artefacts from the AASEAL ethnographic collection'. ${ }^{37}$

\section{Exceptional Objects}

All of the baskets in the various museums holding Expedition material are twined, with one exception: Smithsonian basket E387541. According to the accession cards, the donor for this object was Frank M. Setzler and it was collected at Milingimbi. The record is as follows: 'Bundle technique, strap handle coiled technique. This represents an introduced technique by the missionaries for trade purposes. Foreign to native techniques, similar to the weaving of mats which are sold by the missions. ${ }^{38}$

31 Mountford, C. P. 1956, Records of the American-Australian Scientific Expedition to Arnhem Land. Volume 1: Art, myth and symbolism, Melbourne University Press, Carlton, Vic., plate 88A.

32 M. Smith, Personal communication to L. Hamby, 27 May 2009, Charlottesville, Va.

33 May, The last frontier?, p. 90.

34 D. Haynes, Personal communication to L. Hamby, 2009, Hood Museum of Art, Hanover, NH.

35 May, The last frontier?, pp. 89-91.

36 Basket 51.8.12669, Hood Museum of Art, Dartmouth College, Hanover, NH.

37 May, The last frontier?, p. 91; May, 'Colonial collections of portable art and intercultural encounters in Aboriginal Australia'.

38 Smithsonian, 2008, Accession 178294, Smithsonian Institution, Washington, DC. 
Whether Ellemor sent the basket to Mountford before the division of objects, or whether Setzler or McCarthy obtained the basket personally, is unknown. The Smithsonian basket is most unusual, being the only coiled basket and one that Setzler acknowledges as being made for trade using a non-traditional technique. It is symptomatic of Setzler's methodology of collecting what people were making, rather than soliciting commissioned pieces.

I surmise that there is only one coiled basket in the Expedition collections because the men doing the collecting did not regard coiling as an authentic technique. Coiling had been practised in Arnhem Land since its introduction in the late 1920s on Goulburn Island..$^{39}$ This basket is similar in form to the five baskets, possibly from the Lower Murray River, offered in a 2009 Sotheby's auction in Melbourne. ${ }^{40}$ These were obtained from the Sheard family - long-time friends of Charles Mountfordalong with an Expedition painting from Oenpelli (see Chapman and Russell, this volume). By the late 1940s, many women would have made this style of basket in Arnhem Land. ${ }^{41}$ Perhaps the rationale for not collecting them was that they did not fit into a paradigm of belonging to ancient traditions. That is to say, Mountford did not want them because they were not made using twining - the classic Arnhem Land technique for making baskets. Men and women were primarily making classic twined baskets but they were also making and selling coiled baskets.

In addition to this coiled basket, McCarthy collected fibre items that were classic in form but incorporated manufactured materials. These items would not have been considered 'real ethnographic specimens' by others on the Expedition. Martin Thomas has commented on the Expedition's tendency 'to obscure or overlook the historical conditions of the communities they visited'.$^{42}$ It is likely that the unwritten collecting policy created a bias towards objects with no outside influence or materials. The most commonly used non-traditional material was coloured wool, which appears in objects collected at Milingimbi and other sites. Some armbands have been wrapped with hand-spun string, overlaid with brightred wool that is wrapped into place. At Milingimbi, red wool was spun into string. Objects such as the coiled basket support the idea that many of the works were not commissioned; they were everyday ones, complete with repaired handles.

Milingimbi baskets also incorporated red wool. It was used in outlining stitching in two twined baskets, held by the Australian Museum (E5281 1 and E52812). More than half of the string bags from Milingimbi incorporate red or other coloured wool. Many of the biting or fighting bags are made almost totally from massproduced materials. Pieces of fabric also made their way into baskets. In basket E52798 from the Australian Museum, fabric replaces the usual string handle.

39 Allen, L. and Hamby, L. 2005, 'Links to the south', in L. Hamby (ed.), Twined Together: Kunmadj Njalehnjaleken, Injalak Arts and Crafts, Gunbalanya, NT, pp. 59-65.

40 Sotheby's 2009, Aboriginal Art: Melbourne 2009, Sotheby's, Armadale, Vic., p. 22.

41 Allen and Hamby, 'Links to the south'.

42 Thomas, 'Taking them back', p. 25. 


\section{Linking Objects and People}

The objects collected during the Expedition contribute to a greater understanding of fibre-based practice in 1948, the biases of Expedition members notwithstanding. Examining the items and recording information from museums provide a range of data. When other archival information, such as documents and photographs, are included, a broader picture emerges. This expanded image, combined with information from Indigenous communities, leads to a more meaningful interpretation.

Discussions with people at Milingimbi indicate that the main groups present on the island in 1948 were the Djinang, Gupapuyngu, Djambarrpuyngu, Walamangu and Wangurri clans. They were the makers of most of the objects. Neither the names nor the clan affiliations of individual makers were recorded; however, a few older people can identify some objects. One such knowledgeable person is the Malarra woman Laurie Baymarrwanga. The late Reverend Joe Mawunydjil, the Milingimbi Shire Council Liaison Officer, listened to Baymarrwanga describe the baskets: 'She can tell. She can see the pattern differences.' ${ }^{43}$ He was referring to the designs on baskets from the Expedition that she grouped into moiety divisions of Dhuwa and Yirritja. Some 60 per cent of the known twined baskets from Milingimbi have ochred designs.

The photographs taken at Milingimbi by McCarthy and Setzler have been an essential component of the research. Often they photographed the same scene of unidentified people. Martin Thomas writes about the loss of identities particularly in the 1948 Expedition. Thomas states that 'Mountford's documentation of artists' names is similarly patchy, and the identities of weavers, fibre workers and tool makers are, in many cases, lost forever' ${ }^{4}{ }^{44}$ Fortunately, some Aboriginal people have very good memories and a strong knowledge base and are able to assist. By working closely with Joe Neparrnga Gumbula, a Yolngu researcher, and Ruth Nalmakarra Garrawurra from Milingimbi, identifications have been made of many individuals in the photographs. Both McCarthy and Setzler photographed three women carrying wood with bundles of pandanus on their heads. We can infer that the women they identified - Ngulurra, Djikanmurruwuy Garrawirrtja and Madowk, a Garrawurra woman, and others - made objects from pandanus and might have been the makers of some of the objects from Milingimbi. Other women are Ngulurra, a Djambarrpuyngu woman, and Djarrga. Other women identified in different photographs include Miningal (Wubulkarra), Mudaykala (Gupapuyngu), Djarrga and Lunpupuy.

43 J. Mawunydjil, Personal communication to L. Hamby, 4 April 2008, Milingimbi, NT.

44 Thomas, M. 2010, 'A short history of the Arnhem Land Expedition', Aboriginal History, vol. 34, p. 160. 


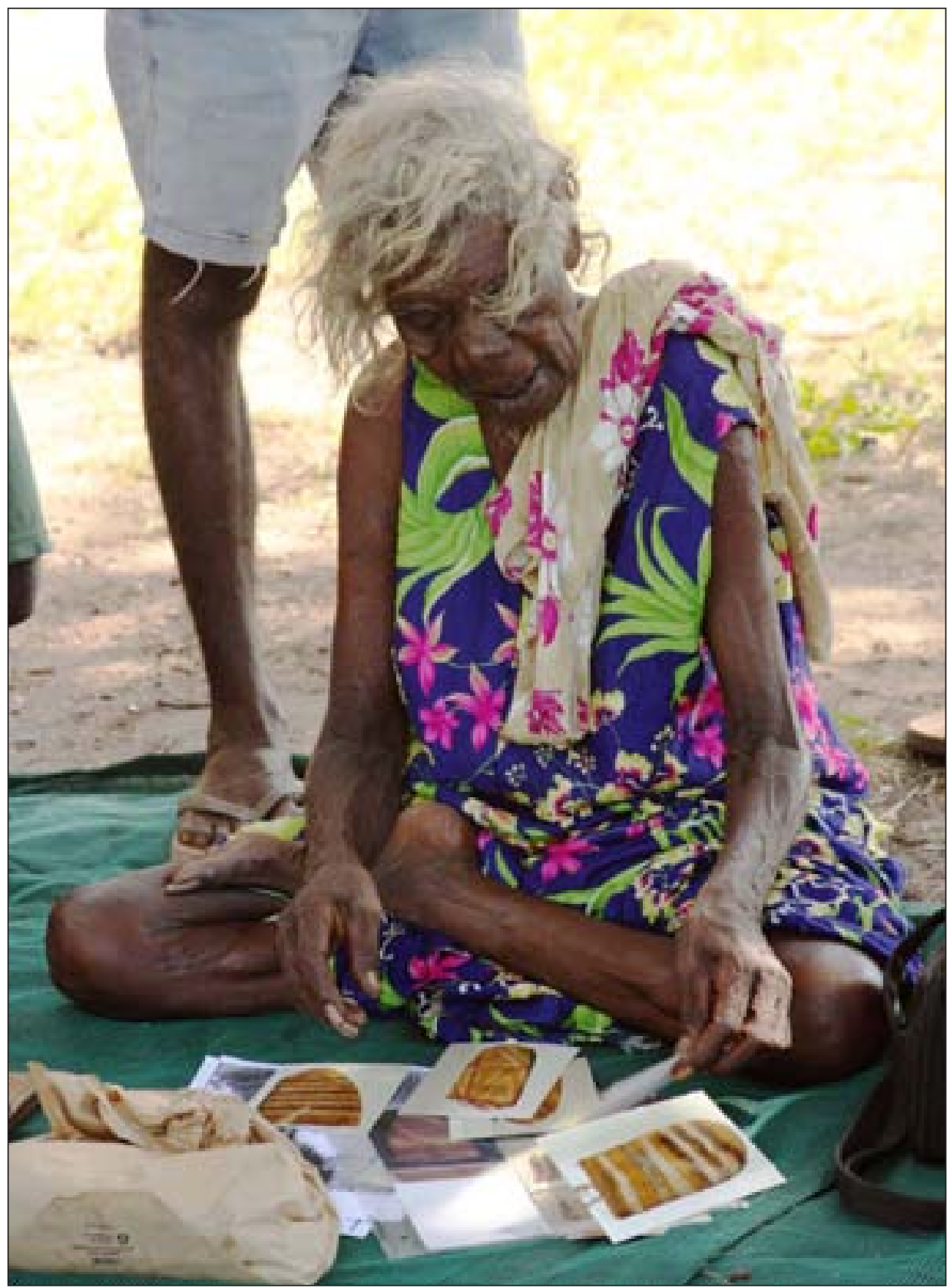

Figure 11.10 Laurie Baymarrwanga looking at baskets from the Expedition, Milingimbi, 15 April 2008

Photograph by Louise Hamby 


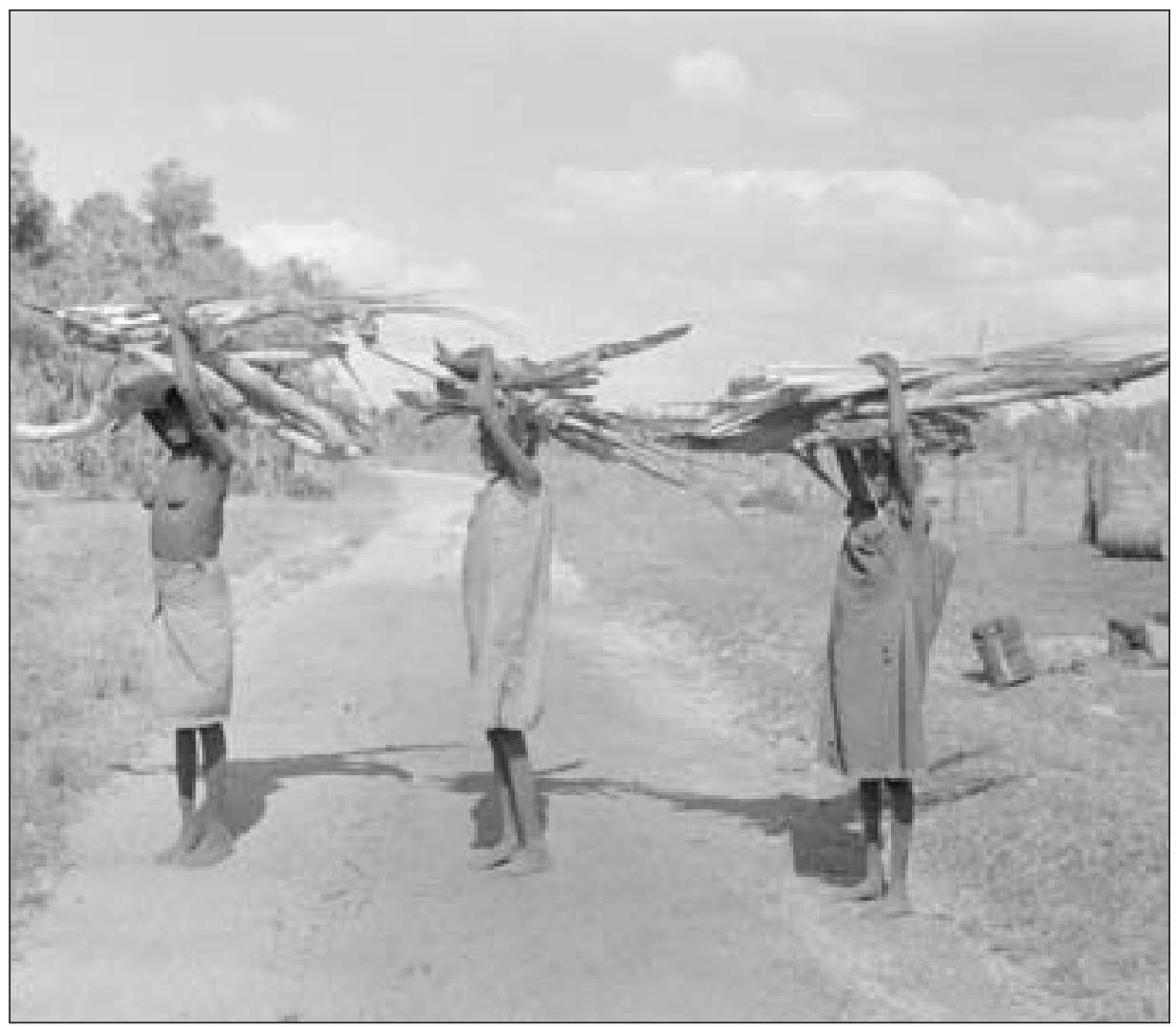

Figure 11.11 Ngulurra (Djambarrpuyngu clan), Djikanmurruwuy (Garrawirrtja clan) and Madowk (Garrawurra clan) carrying pandanus on top of firewood, 1948

Photograph by Frank Setzler. By permission of the National Anthropological Archives, Smithsonian Institution. Frank Setzler Photographs, Photo Lot 36, Box 8, Image 18.

An exciting case study involves a basket from Milingimbi-item E52809-in the Australian Museum. The official records provide minimal information about it. This closely twined basket is distinctively painted, so is unlikely to be an everyday one. I had no other clues to its links with specific people or activities until I was able to connect the basket, diaries and photographs with information gained from Gumbula. 


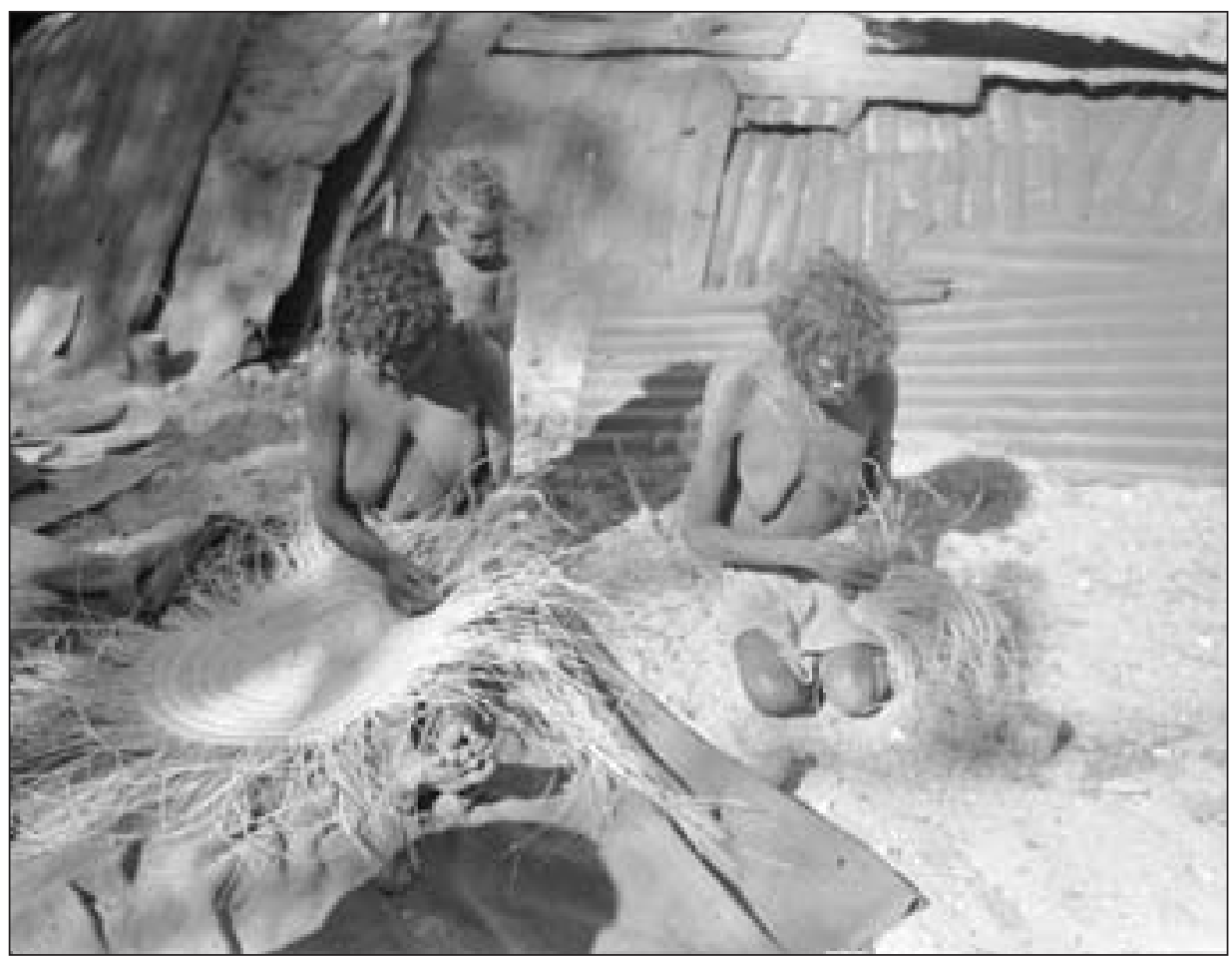

Figure 11.12 Mininyala (Wubulkara clan), Djakala (Garrawurra clan) and Ngulurra (Djambarrpuyngu clan) on the beach at Milingimbi, 1948

Photograph by Frank Setzler. By permission of the National Anthropological Archives, Smithsonian Institution. Frank Setzler Photographs, Photo Lot 36, Box 8, Image 11.

Early in my investigations, when I had access to a few of the photographs taken by Frank Setzler at Milingimbi, I showed his group photograph taken on the beach at Milingimbi to Gumbula. Setzler's description on the negative sleeve is: 'Native children on the beach in front of mission houses on Milingimbi. August 1948.' ${ }^{\prime 5}$ As noted, McCarthy and Setzler frequently photographed the same scenes simultaneously. McCarthy, however, took more photographs of people creating fibre objects. In this case, he took two close-up images of one man who appears in Setzler's group shot on the beach. ${ }^{46}$ On the right-hand side there is a man painting a basket. Gumbula was able to identify eight of the 16 individuals: Manuwa, Lunpupuy, Lityawuy, Fred, Yirrili, Mungunu Gaykamangu, Muntjingu and Banakaka. After documenting the baskets from the American-Australian Scientific Expedition to Arnhem Land and examining photographs, I thought it would be interesting to see if I could find the basket that was being painted

45 F. M. Setzler, 1948, Photo Lot 36, Image 9, Smithsonian Institution National Anthropological Archives, Washington, DC.

46 McCarthy, F. 1957, Australia's Aborigines, Their Life and Culture, Colorgravure Publications, Adelaide; and McCarthy, F. 1974, Australian Aboriginal Decorative Art, Australian Museum, Sydney. 
by Mungunu Gaykamangu in the photograph. Only McCarthy and Setzler were at Milingimbi. I therefore felt that this basket, if it had been collected, would have gone to either the Smithsonian or the Australian Museum. A search of photographs of collected baskets revealed that the Australian Museum does indeed hold the basket, registered as E52809.

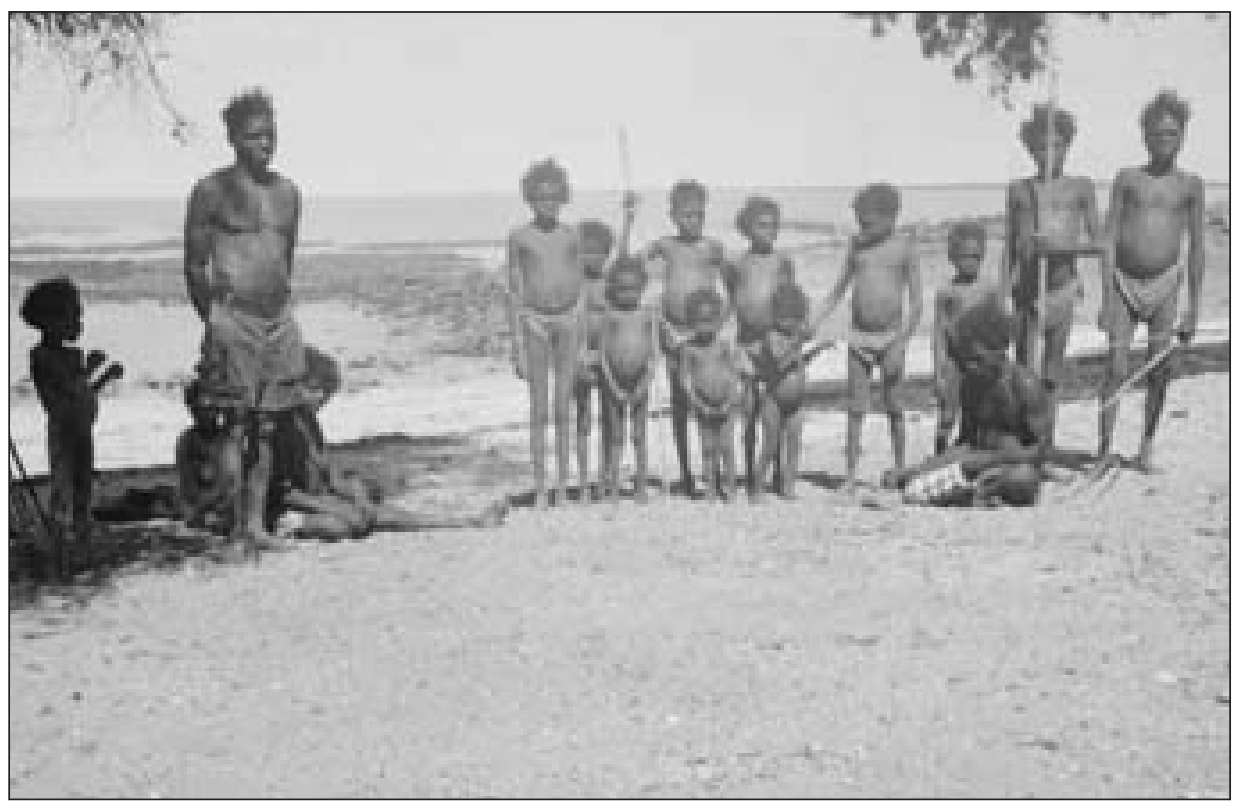

Figure 11.13 A group of people on the beach at Milingimbi. Known individuals, when counted from the left of the image: 3-5, Manuwa, Lunpupuy, Lityawuy; 12-16, Fred, Yirrili, Mungunu Gaykamangu, Muntjingu, Banakaka, 1948 (identifications by Joe Neparrnga Gumbula)

Photograph by Frank Setzler. By permission of the National Anthropological Archives, Smithsonian Institution. Frank Setzler Photographs, Photo Lot 36, Box 8, Image 9.

In February 2009, I met again with Gumbula to show him the photographs. He was convinced that we had located the basket depicted-a ceremonial one from his Gupapuyngu clan. Mungunu Gaykamangu was Gumbula's uncle on his father's side. 


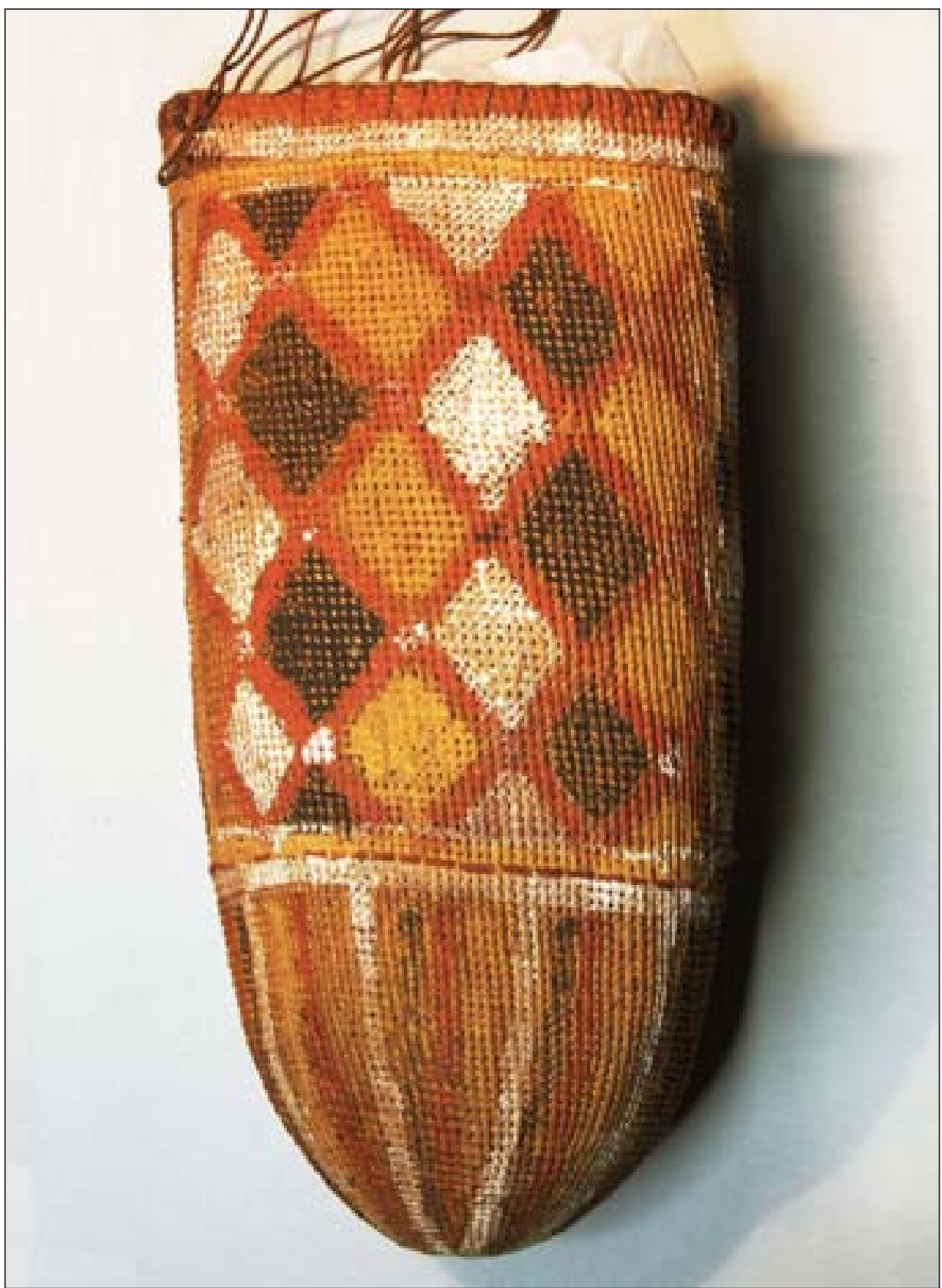

Figure 11.14 Twined basket from Milingimbi

Photograph by Louise Hamby. By permission of the Australian Museum. ID No. E52809. 
In April 2009, Gumbula reflected further on this photograph, the process of identification, and what might become of the basket. There are three categories in Gumbula's system of classifying knowledge, images and objects: garma ('open'), yärra' ('restricted'), and a third broad-access category, dhuni' makarr garma mirr ('sheltered'). The last category is one open to public access, but images should be viewed only with guidance from an appropriate elder. ${ }^{47} \mathrm{He}$ draws an analogy between these protocols and the concept of a traffic light with its three colours. He describes this basket as orange, denoting caution. It would be used in special ceremonies. 'This is a very important basket. Only the elders can carry on. ${ }^{\prime 48} \mathrm{He}$ and his family members are now interested in what the future of this basket might be. In October, he said that he wished to do more consultation with people at Milingimbi and would 'probably sign to get it back' ${ }^{49}$ Without doubt, there are many other baskets that fall into Gumbula's access category of orange and red items. In order to ascertain the orders of classification, much more research is required.

\section{Conclusion}

Research to date has demonstrated that the fibre collection from the Expedition is more significant than previously documented. There are more fibre objects than bark paintings, yet the latter have received much attention. Perhaps their reception would have been different if they too had been distributed at the same time as the division of paintings among gallery directors in Brisbane in $1956 .{ }^{50}$ The numbers collected indicate their importance in the life of the people making and using them. Many were objects in use at the time; they were not made to fit outsiders' concepts of 'real ethnological specimens'. As May points out, McCarthy not only wished to fill gaps in the Australian Museum collection, he wanted 'to collect and record those objects that the expedition members observed being made and used'. ${ }^{51}$ Milingimbi was a different collecting site from the others and is important in that the majority of the items were brought to the collectors, rather than being requested. The collected items represented a slice of life from a material culture view. They are representative of the materials available to their makers in 1948, which include fabric and wool, not just 'classic' materials such as bark fibre and pandanus.

\footnotetext{
47 Gumbula, N., Corn, A. and Mant, J. 2008, 'Matjabala Mali' Buku-RuYanmaram: implications for archives and access in Arnhem Land, The Fourth International Conference on the History of Records and Archives, University of Western Australia, Perth.

48 N. Gumbula, Personal communication to L. Hamby, 28 October 2009, Sydney.

49 Ibid.

50 Neale, M. 1998, 'Charles Mountford and the "bastard barks"', in L. Seear and J. Ewington (eds), Brought to Light: Australian art, Queensland Art Gallery, Brisbane, p. 210.

51 May, The last frontier?, p. 123.
} 
McCarthy and Setzler collected most of the fibre objects, however Mountford might have collected some of these, as did his wife, Bessie. In August, she wrote in her diary, 'I collected one basket, bought a lovely bailer shell, and paid for everything including the mats' ${ }^{52}$ I have not found a basket attributed to her, or the mats. Indeed, there is only one mat in the entire collection. Her name might, however, in time be attached to other items that have not yet been studied. She also collected shell specimens and got her first 'cat-eye' - the operculum or foot-closure on a turban shell- on the same day that her husband bought his first painting at Groote Eylandt. ${ }^{53}$ Perhaps if Bessie Mountford had also gone to Milingimbi we might have seen even more fibre objects. She gave much thought to the events happening around her in Arnhem Land and reflected on the collecting: 'The greed of the collector is understandable. One would have to keep a firm hand on oneself, and have a mind quite clear as to the why's [sic] and basic values of collecting. ${ }^{54}$ According to Craig Elliot, Margaret McArthur also collected baskets, bags and bark containers. ${ }^{55}$

It is unlikely that researchers now will ever know the origins and maker of every piece from the Expedition. The fibre objects will assist in bringing forward knowledge of the social and cultural practices of their era. The connection of people to the objects and photographs from the Expedition is one of the most direct and satisfying aspects of researching this subject. To discover more histories like those at Milingimbi requires additional time and resources, and a commitment to involving Indigenous researchers from the communities. The history of all the objects from the Expedition can be enhanced from collaborative research in the future. Individuals such as Joe Neparrnga Gumbula, an Australian Research Council Fellow, are already pursuing this objective.

\section{Acknowledgments}

I would like to thank the following people. At Milingimbi: Laurie Baymarrwanga, the late Joe Mawunydjil, Joe Neparrnga Gumbula and Ruth Nalmakarra Garrawurra. Museums and their staff: Australian Museum-Phil Gordon and Melanie van Offen; South Australian Museum-Keryn Walshe; National Museum of Australia - Claire Owens, David Kaus and Karen Peterson; Smithsonian-Felicia Pickering; the Australian National University-Maryam Rashidi, Martin Thomas and Sally May.

\footnotetext{
52 B. Mountford, 1948, Diary 3, Friday August 13, p. 17, PRG 487/1/2, SLSA.

53 B. Mountford, 1948, Diary 1, Tuesday April 20, p. 96, PRG 487/1/2, SLSA.

54 B. Mountford, 1948, Diary 3, Thursday September 2, p. 60, PRG 487/1/2, SLSA.

55 Elliott, C. 1992, American Australian Scientific Expedition to Arnhem Land, Unpublished cataloguing consultancy report, National Museum of Australia, Canberra, p. 96.
} 